\title{
INVESTIGATION OF THE MULTIPLE INTELLIGENCE AREAS OF STUDENTS INTRODUCING THE SPECIAL TALENT EXAMINATION FOR HIGHER EDUCATION INSTITUTION
}

\author{
Mehmet Ali Can Uyduran', \\ Uğur Abakay ${ }^{2 i}$ \\ ${ }^{1}$ Gaziantep University, \\ Health Sciences Institute, \\ Turkey \\ ${ }^{2}$ Gaziantep University, \\ Faculty of Sport Sciences, \\ Turkey
}

\begin{abstract}
:
This study is a descriptive study meant to examine the multiple intelligence areas of students who enter the Higher Education Institution with a special talent exam. The research was conducted using the scanning model. The population of the research consists of students who have been placed in Gaziantep University Faculty of Sports Sciences, Turkish Music and State Conservatory and Fine Arts Faculty for the 2018-2019 and 2019-2020 academic years with a special talent exam. The sample group consists of 408 (240 male, 168 female) students selected randomly (Sports Sciences 180, Conservatory 100, Fine Arts 128) In order to collect data in the study, "Self-Assessment Inventory in Multiple Intelligence Domains", developed by Gardner (1993) and translated into Turkish by Saban (2001), was used. SPSS 20.0 (Statistical Packet for the Social Science) package program was used for statistical analysis of the data collected within the framework of the purpose of the research. In the evaluation of general information about students, frequency (f) and percentage (\%), mean (X) and standard deviation (Ss) values were calculated. Independent sample t-test and One Way Anova tests were used for comparisons between groups, Pearson correlation analysis was used for the relationships between age groups and intelligence types, and the significance level was accepted as $p=$ 0.05. According to the results of our research, it has been seen that the students who won higher education with a special talent exam have different intelligence areas according to gender, age, department, income status variables and these intelligence areas develop at different levels. Social, environmental, economic, etc. of these intelligence areas. considered to be affected by the circumstances. It is necessary to evaluate the theory of multiple intelligences not only as a theory of intelligence, but as a philosophy of
\end{abstract}

${ }^{i}$ Correspondence: email alican.9507@gmail.com, uabakay@gmail.com 
education and training. It is also important for individuals to be aware of their own intelligence areas in terms of their role in the learning environment.

Keywords: sports sciences, special talent, fine arts, conservatory, multiple intelligence

\section{Introduction}

From the moment a person opens his eyes to the world, he becomes a part of the society he lives in. He is in contact with all people since birth, and education is the most important tool in this communication process (1). Education is very important in terms of directing the present and future of society. For this reason, education cannot be left to chance and starts in the family, develops with environmental factors, and is reinforced by education in schools (2).

When we examine the understanding of education until today, it has been thought that the knowledge is certain and unchangeable, and according to this understanding, it is believed that it will be sufficient to transfer the knowledge in the books to the students superficially. Only two-way development of numerical and verbal intelligence in students is aimed (3). Since 20th century, this understanding of education has evolved into an understanding that individuals are more active in the learning process and can actively use what they have learned in their daily lives. The purpose of this understanding, in which individuals are more active, is to ensure that students become more active in learning instead of being passive, and to train students to participate more actively in learning processes, to help them produce solutions to the problems they encounter, encourage them to set goals for themselves and achieve these goals (4).

Intelligence has become an important concept in people's desire to dominate their environment and nature as a result of self-understanding and self-discovery of people with bio-psycho-social characteristics. As a result of this, researchers have presented different theories and applications on the concept of intelligence (5).

Some studies have been done on the concept of intelligence and as a result of these studies, new information has been added to the sources (6). The concept of intelligence was previously seen as an abstract thinking skill with only verbal and numerical symbols. Later, the idea emerged that intelligence should be explained by two factors. Because it was believed that the idea of explaining intelligence with abstract thinking skills would be incomplete. The mentioned double factor is explained as general ability and special ability. What is meant by general ability is intelligence itself, similar to the one-factor understanding. Factors that occur as a result of differences in individuals are considered as special abilities (7). However, it was thought that there were deficiencies in this approach and that intelligence did not consist of a few skills, and the theory of multiple intelligences was put forward by Gardner (1983). The main point in the theory of multiple intelligences is the word "multiple". From this point of view, it is thought that mental skills can be constantly differentiated and should not be restricted. 
Howard Gardner introduced the theory of multiple intelligences in his book titled "Frames of Mind" in 1983 and mentioned intelligence areas for the first time in this book (8). As a result of the definition of multiple intelligences, Gardner said that intelligence consists of eight different areas. Bodily (kinesthetic) intelligence, naturalistic (natural) intelligence, visual (spatial) intelligence, intrapersonal (introspective) intelligence, logical (mathematical) intelligence, musical (rhythmic) intelligence, social (interpersonal) intelligence, verbal (linguistic) intelligence. If we exemplify the intelligence areas through the basketball player; An example of a player's dribbling, passing and shooting is physical intelligence, being in contact with his friends during the game is social intelligence, self-evaluation during and after the game is intrapersonal intelligence, recognizing the playing area is visual intelligence, and learning the rules of the basketball game is linguistic intelligence (9).

In this study, in line with the information given above, it was aimed to investigate the effect of intelligence on admission to universities that accept students with special talent exams, determining the dominant intelligence type among different intelligence dimensions, and whether there is a meaningful relationship between university and intelligence through different variables. For this purpose, an answer to the following question was sought.

How does the department where students are accepted relate to intelligence areas according to multiple intelligence theory? Is there a significant difference between these intelligence areas according to the variables?

\section{Method}

This study is a descriptive meant study to examine the multiple intelligence areas of students who enter the Higher Education Institution with a special talent exam. The research was conducted using the scanning model. The population of the research consists of students who were accepted to Gaziantep University Faculty of Sports Sciences, Turkish Music and State Conservatory and Fine Arts Faculty for the 2018-2019 and 2019-2020 academic years with a special talent exam. The sample group consists of 408 (240 male, 168 female) students selected randomly. In order to collect data in the study, the "Self-Assessment in Multiple Intelligence Domains Inventory", developed by Gardner (1993) and translated into Turkish by Saban (2001), was used. The Cronbach alpha value of the scale was $0.93(10,11)$. The data were analyzed using the SPSS 20.0 program. Independent sample t-test and One Way Anova tests were used for comparisons between groups, Pearson correlation analysis was used for the relationships between age groups and intelligence types, and the level of significance was accepted as $\mathrm{p}=0.05$. 


\section{Results}

In this part of the research, the findings obtained from the analysis of the data are presented in the form of tables and explanations under the tables.

Table 1: Distribution of scores obtained from intelligence areas according to departments

\begin{tabular}{|c|c|c|c|c|c|}
\hline $\begin{array}{l}\text { Intelligence } \\
\text { Areas }\end{array}$ & Section Variable & $\mathbf{N}$ & Mean & Ss & $\begin{array}{c}\text { Level of } \\
\text { Development }\end{array}$ \\
\hline \multirow{3}{*}{$\begin{array}{l}\text { Logical } \\
\text { Intelligence }\end{array}$} & Sports Sciences & 180 & 24,61 & 7,56 & Partially \\
\hline & Conservatory & 100 & 20,98 & 8,18 & Partially \\
\hline & Fine Arts & 128 & 22,79 & 7,38 & Partially \\
\hline \multirow{3}{*}{$\begin{array}{l}\text { Verbal } \\
\text { Intelligence }\end{array}$} & Sports Sciences & 180 & 33,82 & 6,05 & Highly \\
\hline & Conservatory & 100 & 27,96 & 5,14 & Partially \\
\hline & Fine Arts & 128 & 29,61 & 6,45 & Partially \\
\hline \multirow{3}{*}{$\begin{array}{l}\text { Visual } \\
\text { Intelligence }\end{array}$} & Sports Sciences & 180 & 28,00 & 7,09 & Partially \\
\hline & Conservatory & 100 & 31,52 & 4,91 & Highly \\
\hline & Fine Arts & 128 & 31,67 & 5,40 & Highly \\
\hline \multirow{3}{*}{$\begin{array}{l}\text { Musical } \\
\text { Intelligence }\end{array}$} & Sports Sciences & 180 & 26,20 & 8,23 & Partially \\
\hline & Conservatory & 100 & 35,86 & 7,71 & Highly \\
\hline & Fine Arts & 128 & 21,96 & 8,27 & Partially \\
\hline \multirow{3}{*}{$\begin{array}{l}\text { Naturalistic } \\
\text { Intelligence }\end{array}$} & Sports Sciences & 180 & 30,30 & 7,24 & Highly \\
\hline & Conservatory & 100 & 30,54 & 6,27 & Highly \\
\hline & Fine Arts & 128 & 25,64 & 8,22 & Partially \\
\hline \multirow{3}{*}{$\begin{array}{l}\text { Bodily } \\
\text { Intelligence }\end{array}$} & Sports Sciences & 180 & 36,16 & 3,01 & Highly \\
\hline & Conservatory & 100 & 28,28 & 6,47 & Partially \\
\hline & Fine Arts & 128 & 29,46 & 6,05 & Partially \\
\hline \multirow{3}{*}{$\begin{array}{l}\text { Intrapersonal } \\
\text { Intelligence }\end{array}$} & Sports Sciences & 180 & 27,88 & 6,20 & Partially \\
\hline & Conservatory & 100 & 33,36 & 5,99 & Highly \\
\hline & Fine Arts & 128 & 22,66 & 5,24 & Partially \\
\hline
\end{tabular}

Table 1 shows the distribution of the scores obtained by the research group in the areas of intelligence. In general, it has been determined that the intelligence levels are at least partially at the level of development. In addition, the intelligence areas that are prominent in terms of development level according to the departments are as follows.

It has been determined that the students of sports sciences are quite advanced in the areas of verbal intelligence, natural intelligence and bodily intelligence, the students of the Conservatory are quite advanced in the areas of visual, musical, naturalistic and intrapersonal intelligence, and the students of fine arts are at a highly advanced level in the area of visual intelligence. 

THE SPECIAL TALENT EXAMINATION FOR HIGHER EDUCATION INSTITUTION

\begin{tabular}{|c|c|c|c|c|c|c|c|}
\hline $\begin{array}{l}\text { Intelligence } \\
\text { Areas }\end{array}$ & & KT & sd & KO & $\mathbf{F}$ & $\mathrm{p}$ & $\begin{array}{l}\text { Significant } \\
\text { Difference }\end{array}$ \\
\hline \multirow{3}{*}{$\begin{array}{l}\text { Logical } \\
\text { Intelligence }\end{array}$} & Between groups & 871,837 & 2 & 435,919 & \multirow{3}{*}{7,422} & \multirow{3}{*}{,001 } & \multirow{3}{*}{$\begin{array}{l}1-2 \\
1-3\end{array}$} \\
\hline & In-group & 23786,042 & 405 & 58,731 & & & \\
\hline & Total & 24657,880 & 407 & & & & \\
\hline \multirow{3}{*}{$\begin{array}{l}\text { Verbal } \\
\text { Intelligence }\end{array}$} & Between groups & 2603,723 & 2 & 1301,862 & \multirow{3}{*}{36,436} & \multirow{3}{*}{,000 } & \multirow{3}{*}{$\begin{array}{l}1-2 \\
1-3\end{array}$} \\
\hline & In-group & 14470,620 & 405 & 35,730 & & & \\
\hline & Total & 17074,343 & 407 & & & & \\
\hline \multirow{3}{*}{$\begin{array}{l}\text { Visual } \\
\text { Intelligence }\end{array}$} & Between groups & 2365,243 & 2 & 1182,622 & \multirow{3}{*}{26,126} & \multirow{3}{*}{,000 } & \multirow{3}{*}{$\begin{array}{l}2-1 \\
3-1\end{array}$} \\
\hline & In-group & 18332,835 & 405 & 45,266 & & & \\
\hline & Total & 20698,078 & 407 & & & & \\
\hline \multirow{3}{*}{$\begin{array}{l}\text { Musical } \\
\text { Intelligence }\end{array}$} & Between groups & 1496,804 & 2 & 748,402 & \multirow{3}{*}{11,360} & \multirow{3}{*}{, 000 } & $2-1$ \\
\hline & In-group & 26681,645 & 405 & 65,881 & & & $2-3$ \\
\hline & Total & 28178,449 & 407 & & & & $1-3$ \\
\hline \multirow{3}{*}{$\begin{array}{l}\text { Naturalistic } \\
\text { Intelligence }\end{array}$} & Between groups & 1981,568 & 2 & 990,784 & \multirow{3}{*}{18,361} & \multirow{3}{*}{,000 } & \multirow{3}{*}{$\begin{array}{l}1-3 \\
2-3\end{array}$} \\
\hline & In-group & 21854,109 & 405 & 53,961 & & & \\
\hline & Total & 23835,676 & 407 & & & & \\
\hline \multirow{3}{*}{$\begin{array}{l}\text { Bodily } \\
\text { Intelligence }\end{array}$} & Between groups & 5319,080 & 2 & 2659,540 & \multirow{3}{*}{103,446} & \multirow{3}{*}{,000 } & \multirow{3}{*}{$\begin{array}{l}1-2 \\
1-3\end{array}$} \\
\hline & In-group & 10412,292 & 405 & 25,709 & & & \\
\hline & Total & 15731,373 & 407 & & & & \\
\hline \multirow{3}{*}{$\begin{array}{l}\text { Intrapersonal } \\
\text { Intelligence }\end{array}$} & Between groups & 3667,032 & 2 & 1833,516 & \multirow{3}{*}{53,299} & \multirow{3}{*}{,000 } & $1-3$ \\
\hline & In-group & 13932,145 & 405 & 34,400 & & & $2-1$ \\
\hline & Total & 17599,176 & 407 & & & & $2-3$ \\
\hline
\end{tabular}

In Table 2, the comparison of the scores obtained by the research group from the scale in terms of the department studied is given. As a result of the analysis, significant differences were found in all intelligence areas in the comparison of the intelligence areas of the groups $(p<0.05)$. According to the results of the LSD test performed to determine the difference between the groups, the following were determined:

- Sports science students achieved higher scores than others in the area of physical, verbal and logical intelligence,

- In the area of visual intelligence, sports science students achieved lower scores than others,

- Conservatory students scored higher than others in musical intelligence, and sports science students scored higher than fine arts students,

- In the area of natural intelligence, students of sports sciences and conservatories achieved higher scores than students of fine arts,

- In the area of intrapersonal intelligence, it was determined that conservatory students scored higher than others, and sports science students scored higher than fine arts students. 

THE SPECIAL TALENT EXAMINATION FOR HIGHER EDUCATION INSTITUTION

Table 3: Comparison of intelligence areas in terms of gender variable of the research group

\begin{tabular}{|c|c|c|c|c|c|c|}
\hline & Gender & $\mathbf{N}$ & Mean & ss & $t$ & $p$ \\
\hline \multirow{2}{*}{$\begin{array}{l}\text { Logical } \\
\text { Intelligence }\end{array}$} & Male & 240 & 22,60 & 8,05 & \multirow{2}{*}{$-1,724$} & \multirow{2}{*}{0,086} \\
\hline & Female & 168 & 23,93 & 7,33 & & \\
\hline \multirow{2}{*}{$\begin{array}{l}\text { Verbal } \\
\text { Intelligence }\end{array}$} & Male & 240 & 30,94 & 6,58 & \multirow{2}{*}{$-0,473$} & \multirow{2}{*}{0,636} \\
\hline & Female & 168 & 31,24 & 6,34 & & \\
\hline \multirow{2}{*}{$\begin{array}{l}\text { Visual } \\
\text { Intelligence }\end{array}$} & Male & 240 & 27,50 & 7,36 & \multirow{2}{*}{$-1,484$} & \multirow{2}{*}{0,139} \\
\hline & Female & 168 & 28,55 & 6,77 & & \\
\hline \multirow{2}{*}{$\begin{array}{l}\text { Musical } \\
\text { Intelligence }\end{array}$} & Male & 240 & 23,90 & 9,05 & \multirow{2}{*}{$-2,723$} & \multirow{2}{*}{0,007} \\
\hline & Female & 168 & 26,06 & 6,98 & & \\
\hline \multirow{2}{*}{$\begin{array}{l}\text { Naturalistic } \\
\text { Intelligence }\end{array}$} & Male & 240 & 27,86 & 7,64 & \multirow{2}{*}{$-3,317$} & \multirow{2}{*}{0,001} \\
\hline & Female & 168 & 30,38 & 7,45 & & \\
\hline \multirow{2}{*}{$\begin{array}{l}\text { Bodily } \\
\text { Intelligence }\end{array}$} & Male & 240 & 31,70 & 6,63 & \multirow{2}{*}{$-1,733$} & \multirow{2}{*}{0,094} \\
\hline & Female & 168 & 32,74 & 5,54 & & \\
\hline \multirow{2}{*}{$\begin{array}{l}\text { Intrapersonal } \\
\text { Intelligence }\end{array}$} & Male & 240 & 26,20 & 6,92 & \multirow{2}{*}{$-2,492$} & \multirow{2}{*}{0,013} \\
\hline & Female & 168 & 27,79 & 5,95 & & \\
\hline
\end{tabular}

Table 3 shows the comparison of intelligence areas of the research group in terms of gender variable. Accordingly, significant differences were found in favor of women in the areas of musical, naturalistic and intrapersonal intelligence $(\mathrm{p}<0.05)$.

Table 4: The relationship between the age variable of the research group and intelligence types

\begin{tabular}{|l|c|c|c|c|c|c|}
\hline \multirow{2}{*}{} & \multicolumn{9}{|c|}{ Age } \\
\cline { 2 - 7 } & \multicolumn{2}{|c|}{ Sports Sciences } & \multicolumn{2}{c|}{ Conservatory } & \multicolumn{2}{c|}{ Fine Arts } \\
\cline { 2 - 7 } & $\mathbf{r}$ & $\mathbf{p}$ & $\mathbf{r}$ & $\mathbf{p}$ & $\mathbf{r}$ & $\mathbf{P}$ \\
\hline Logical Intelligence & 0,053 & 0,483 & 0,196 & 0,051 & $-0,088$ & 0,324 \\
\hline Verbal Intelligence &, $178^{*}$ & 0,017 &, $108^{* *}$ & 0,283 &, $167^{* *}$ & 0,059 \\
\hline Visual Intelligence & 0,12 & 0,11 & 0,134 & 0,184 &, $190^{*}$ & 0,032 \\
\hline Musical Intelligence &, $240^{* *}$ & 0,001 &, $254^{*}$ & 0,011 &, $206^{*}$ & 0,02 \\
\hline Naturalistic Intelligence &, $315^{* *}$ & 0,000 &, $341^{* *}$ & 0,001 &, $229^{* *}$ & 0,009 \\
\hline Bodily Intelligence &, $153^{*}$ & 0,041 &, 199 & 0,057 & 0,06 & 0,499 \\
\hline Intrapersonal Intelligence & 0,132 & 0,078 &, $269^{* *}$ & 0,007 & 0,084 & 0,344 \\
\hline
\end{tabular}

In Table 4, the results of the correlation analysis regarding the relationships between the age variable of the research group and the intelligence areas are given.

A weak positive correlation was found between the age variable of sports science students and verbal, musical, naturalistic and bodily intelligence areas. Therefore, it can be said that there is an increase in verbal, musical, natural and bodily intelligence areas with the increase in age in sports science students. A weak positive correlation was found between the age variable of conservatory students and verbal, musical, naturalistic and intrapersonal intelligence areas. Therefore, it can be said that there is an increase in verbal, musical, naturalistic and intrapersonal intelligence areas with the increase in age in conservatory students.

A weak positive correlation was found between the age variable of fine arts students and verbal, visual, musical and natural intelligence areas. Therefore, it can be 
said that there is an increase in verbal, visual, musical and natural intelligence areas with the increase in age in conservatory students.

\section{Discussion and Conclusion}

When the distribution of the scores obtained by the research group in the intelligence areas is examined, it has been determined that the intelligence levels are at least partially at the level of development. However, it has been concluded that the students of sports sciences are at a highly developed level in the areas of verbal intelligence, natural intelligence and bodily intelligence, the students of the Conservatory are quite advanced in the areas of visual, musical, naturalistic and intrapersonal intelligence, and the students of fine arts are at a highly advanced level in the area of visual intelligence.

The Multiple Intelligence theory adopts the idea that the intelligence existing in humans is not only in a single intelligence area, but is distributed across all intelligence areas. The level of development of each of the intelligence areas in humans may differ from each other. In other words, in some people, any of the intelligence areas may exist at a developed level, while other intelligence areas may exist at a moderate or very underdeveloped level (12). When we look at the studies conducted in the area, there are findings that the bodily kinesthetic intelligence areas of the individuals engaged in sports are more developed $(13,14,15,16)$.

Gardner (1997) stated that if individuals recognize various intelligence elements, their potential to produce solutions to the problems they encounter may be higher, the thinking method of each individual is different, and if these differences are taken into account in the education given to individuals, this can be beneficial to individuals in the most efficient way (17). It is thought that the fact that the intelligence areas that are constantly used are different is an important factor in the differentiation of intelligence areas according to the departments. Our study supports this notion.

When we look at the comparison of intelligence areas in terms of special talent exam and departments that admit students, the following results were obtained: sports science students scored higher than the others in the physical, verbal and logical intelligence areas. In the area of visual intelligence, sports science students scored lower than the others. Conservatory students scored higher in musical intelligence than others, and sports science students scored higher than fine arts students. In the area of natural intelligence, sports science and conservatory students achieved higher scores than fine arts students. In intrapersonal intelligence, conservatory students scored higher than others, and sports science students scored higher than fine arts students. Studies in the area support the results we obtained in our study $(18,19,20,21,22,23)$.

Considering the comparison of intelligence areas of the research group in terms of gender variable, it was seen that women achieved higher scores than men in musical, naturalistic and intrapersonal intelligence areas. Sports science students had more positive scores than women in the area of natural intelligence. Conservatory students had more positive scores than women in the areas of logical and visual intelligence. Fine arts 
students had more positive scores than women in the area of visual intelligence. In the studies, it was seen that there were results in favor of women in the areas of musical, intrapersonal and natural intelligence, and results in favor of men in the areas of physical, social and logical intelligence $(16,22,24,25,26,27,28,29)$.

When we look at the results of the correlation analysis regarding the relationships between the age variable and the intelligence areas, it can be said that there is an increase in the verbal, musical, natural and bodily intelligence areas with the increase in age in the sports science students. It can be said that there is an increase in verbal, musical, naturalistic and intrapersonal intelligence areas with the increase in age in conservatory students. It can be said that there is an increase in verbal, visual, musical and natural intelligence areas with the increase in age in fine arts students. Studies have shown that there is a relationship between the age variable and intelligence areas $(21,24,30,31,32$, 33).

According to the results of our research, it has been seen that the students who are accepted to higher education with a special talent exam have different intelligence areas according to the variables of gender, age, department, income status, and these intelligence areas develop at different levels. It is thought that areas of intelligence are affected by social, environmental, economic situations. It is necessary to evaluate the theory of multiple intelligences not only as a theory of intelligence, but as a philosophy of education and training. It is also important for individuals to be aware of their own intelligence areas in terms of their role in the learning environment. Departments that conduct special talent exams can make additions similar to the following in special talent exams: Special talent exams can be introduced in the Faculty of Sports Sciences, not only according to the area of physical intelligence, but also covering other intelligence areas of individuals.

\section{Conflict of Interest Statement}

There are no potential conflicts of interest on this article.

\section{About the Authors}

Mr. Mehmet Ali Can Uyduran has Master of Science degree in the sport science field. Dr. Uğur Abakay is Associated Professor Doctor at Gaziantep University, Turkey.

\section{References}

1. Erdem A. R. Eğitim sistemini geliştirme planı. Pamukkale Üniversitesi Eğitim Fakültesi Dergisi. 2000;7(7):153-161.

2. Chongde L., Tsingan L. Multiple intelligence and the structure of thinking. Theory Psychology. 2003;13:829-845.

3. Görücü A. Beden eğitiminde yeni bir yaklaşım çoklu zeka kuramı. Konya: Me-Sa Kitabevi, 2008: s.1. 
4. Nacakcı, Z. Çoklu zeka kuramı dayanaklı ders işleme modelinin ilköğretim 7. sınıf müzik dersinde öğrencilerin müziksel öğrenme düzeylerine etkisi. 2006, Gazi Üniversitesi, Eğitim Bilimleri Enstitüsü, Doktora tezi, 184 sayfa, Ankara, (Prof. Dr. Ali Uçan).

5. Gardner H. Intelligence Reframed: Multiple Intelligences fot The 21st Ceuntry. New York: Basic Book, 1999.

6. Tomporowski PD, Davis CL, Miller PH and Naglieri JA. Exercise and Children's Intelligence, Cognition and Academic Achievement. Educ Psychol Rev. 2008;20:111-131.

7. Özden Y. Öğrenme ve Öğretme, 5. baskı. Ankara: Pegem Yayıncılık, 2003.

8. Gardner H, 1983, Frames of Mind. Zihnin Çerçeveleri: Çoklu Zeka Kuramı, Kılıç E, Alfa Yayınları, İstanbul, 2004.

9. Gardner H. Frames of Mind: The Theory of Multiple Intelligences (2nd Edition). New York: NY: Basic Books, 1993.

10. Gardner H. Multiple intelligences: the theory in practice. New York: Published by Basic Books, 1993.

11. Saban A. Çoklu Zeka Teorisi ve Eğitim, 1. Baskı. Ankara: Nobel Yayın Evi, 2001.

12. Arı R, Saban A. Sınıf Yönetimi. Konya: Ceylan Ofset, 2000.

13. Bilir, F. P, Şirin Y. Analysis of Bridge Player Profiles According to Their Intelligence Areas. Journal of Education and Training Studies. 2017;5(9):100-108.

14. Kahraman D. İ, Bavlı Ö. Üniversitenin Farklı Bölümlerinde Okuyan Öğrencilerin Çoklu Zeka Alanlarının İncelenmesi. International Journal of New Trends in Arts, Sports \& Science Education. 2014;3(3): 65-71.

15. Altınok E. Beden Eğitimi Öğrencilerinin Bazı Değişkenlere Göre Çoklu Zeka Alanlarının İncelenmesi. 2008, Selçuk Üniversitesi, Sağlık Bilimleri Enstitüsü, Yüksek Lisans tezi, Konya, 54 sayfa, (Yrd. Doç. Dr. Yalçın Kaya).

16. Çinkılıç İ, Soyer F. Beden eğitimi öğretmen adaylarının çoklu zekâ alanları ile problem çözme becerileri arasındaki ilişkinin incelenmesi. Spor Yönetimi ve Bilgi Teknolojileri Dergisi. 2013;8(1):4-16.

17. Baran M, Maskan A. K. 11. sınıf öğrencilerinin çoklu zekâ alanlarının bazı değişkenler ve fizik dersi başarıları açısından incelenmesi. Necatibey Eğitim Fakültesi Elektronik Fen ve Matematik Eğitimi Dergisi. 2011;5(2),156-177.

18. Dalkıran E. Müzik eğitimi ve resim eğitimi öğrencilerinin çoklu zekâ alanlarının bazı değişkenlere göre karşılaştırılması. Mehmet Akif Ersoy Üniversitesi Sosyal Bilimler Enstitüsü Dergisi. 2017;9(22):225-23.

19. Hoşgörür V, Katrancı $M$. Sınıf ve beden eğitimi ve spor öğretmenliği öğrencilerinin baskın zeka alanları (Kırıkkale Üniversitesi Eğitim Fakültesi Örneği). Ondokuz Mayıs Üniversitesi Eğitim Fakültesi Dergisi. 2007;24:33-42.

20. Ermis E, Imamoğlu O. The effect of doing sports on the multiple intelligences of university students. International Journal of Academic Research Part B. 2013;5(5): 174-179. 
21. Avcı P. Spor Bilimleri Fakültesi İle Diğer Fakülte Öğrencilerinin Çoklu Zeka Alanları ve Problem Çözme Becerilerinin Çeşitli Değişkenler Açısından İncelenmesi. 2018,Selçuk Üniversitesi, Sağlık Bilimleri Enstitüsü, Yüksek Lisans tezi, Konya, 101 sayfa, (Doç. Dr. Alpaslan Görücü).

22. İzci E, Sucu H. Üniversite öğrencilerinin çoklu zekâ profillerinin incelenmesi (Nevşehir Üniversitesi Örneği). İnönü Üniversitesi Eğitim Bilimleri Enstitüsü Dergisi. 2014;1(1):12-21.

23. Tural M. Beden Eğitimi ve Spor Yüksekokulu Bölümlerinde Okuyan Öğrencilerin Çoklu Zeka Kuramına Göre Karşılaştırılması. 2009, Gazi Üniversitesi, Eğitim Bilimleri Enstitüsü, Yüksek Lisans tezi, Ankara, 95 sayfa, (Yrd. Doç. Dr. Nevin Atalay Güzel).

24. Kemeç D. G. Türk Halk Oyunları Bölümü İle Beden Eğitimi Ve Spor Yüksekokulu Öğrencilerinin Çoklu Zekâ Alanlarının Karşılaştırılması. 2016, Gazi Üniversitesi, Eğitim Bilimleri Enstitüsü, Yüksek Lisans tezi, Ankara, 102 sayfa, (Prof. Dr. Mehmet Günay).

25. Okur E, Yalçın Özdilek Ş, Sezer B. Çoklu zekâ alanlarının çeşitli değişkenler açısından incelenmesi. Kastamonu Eğitim Dergisi. 2013;21(2):737-758.

26. Pirgon Y. Müzik öğretmeni adaylarının çoklu zekâ profillerinin piyano ve bireysel çalgı dersi başarıları ve bazı değişkenler açısından karşılaştırılması. EKEV Akademi Dergisi. 2020:24(81);539-554.

27. İzci E, Kara A, Dalaman F. Dershane öğrencilerinin çoklu zekâ kuramı açısından incelenmesi. Pamukkale Üniversitesi Eğitim Fakültesi Dergisi. 2007:21(1);1-14.

28. Güllü M, Tekin M. Spor lisesi öğrencileri ile genel lise öğrencilerinin çoklu zekâ alanlarının karşılaştırılması. Niğde Üniversitesi Beden Eğitimi ve Spor Bilimleri Dergisi. 2009:3(3);247-258.

29. Ürgüp S. Beden Eğitimi ve Spor Yüksek Okulunun Üç Farklı Bölümünde Eğitim Gören Öğrencilerin Çoklu Zeka Alanlarının İncelenmesi. 2015, Cumhuriyet Üniversitesi, Sağlık Bilimleri Enstitüsü, Yüksek Lisans tezi, Sivas, 56 sayfa, (Yrd. Doç. Dr. Cem Sinan Aslan).

30. Polat D. Spor Bilimleri Alanında Özel Yetenek Sınavına Giren Adayların Çoklu Zekâ Alanlarının İncelenmesi. 2018, Gaziantep Üniversitesi, Sağlık Bilimleri Enstitüsü, Yüksek Lisans tezi, Gaziantep, 63 sayfa, (Doç. Dr. Mürsel Biçer).

31. Altınmakas O. Elit Basketbol Oyuncularının Oynadıkları Mevkilere Göre Çoklu Zekâ Dağılımlarının İncelenmesi. 2011, Gazi Üniversitesi Eğitim Bilimleri Enstitüsü, Yüksek Lisans Tezi, Ankara, 103 sayfa, (Yrd. Doç. Dr. Muhsin Hazar).

32. Hamurcu H, Günay Y, Özyılmaz G. Buca eğitim fakültesi fen bilgisi ve sınıf öğretmenliği bölümü öğrencilerinin çoklu zeka kuramına dayalı profilleri. V. Ulusal Fen ve Matematik Eğitimi Sempozyumu Bildiriler Kitabı. 2002:1;415-421.

33. Sivrikaya K, Aydın S. Elit atıcıların çoklu zekâ özelliklerinin cinsiyet, kullandıkları silah türü ve yaş faktörlerine göre karşılaştırılması. İstanbul Aydın Üniversitesi Eğitim Fakültesi Dergisi. 2017:3(2);79-94. 
Authors will retain the copyright of their published articles agreeing that a Creative Commons Attribution 4.0 International License (CC BY 4.0) terms will be applied to their work. Under the terms of this license, no permission is required from the author(s) or publisher for members of the community to copy, distribute, transmit or adapt the article content, providing a proper, prominent and unambiguous attribution to the authors in a manner that makes clear that the materials are being reused under permission of a Creative Commons License. Views, opinions and conclusions expressed in this research article are views, opinions and conclusions of the author(s). Open Access Publishing Group and European Journal of Physical Education and Sport Science shall not be responsible or answerable for any loss, damage or liability caused in relation to/arising out of conflict of interests, copyright violations and inappropriate or inaccurate use of any kind content related or integrated on the research work. All the published works are meeting the Open Access Publishing requirements and can be freely accessed, shared, modified, distributed and used in educational, commercial and non-commercial purposes under a Creative Commons attribution 4.0 International License (CC BY 4.0). 